\title{
Women on Board: Female Board Membership as a Form of Elite Democratization
}

\author{
EELKE MICHIEL HEEMSKERK \\ MEINDERT FENNEMA
}

Corporate elites have been all-male bastions until the twenty-first century. The recent inclusion of women in the corporate elite needs explanation because it is an abrupt change in recruitment practices. We consider female presence in corporate boards as a sign of the democratization of elite social networks. Building on a case study of the Netherlands that covers the last four decades, we show that the corporate elite has become more open to nonmembers of traditional elites. In the process, women have also entered the boardroom. Initially, these were predominantly female politicians, but more recently many large corporations have recruited foreign females. We argue that the incremental feminization of the corporate elite was in the beginning — that is in the 1970s_-initiated by the state but was subsequently pushed forward by the internationalization of corporate governance. We have traced the professional background of all

() The Author 2014. Published by Oxford University Press on behalf of the Business History Conference. All rights reserved. For permissions, please e-mail: journals.permissions@oup.com

doi:10.1093/es/kht136

Advance Access publication January 24, 2014

EeLKe M. HEEMSKERK is Assistant Professor of Political Science at the University of Amsterdam. He published on corporate governance, corporate elites, social networks, and institutional reform in the Netherlands and Europe, including among others Decline of the Corporate Community (AUP 2008), The Fading of the State (IJCS 2012), and the Rise of the European Corporate Elite (Economy and Society 2013). Contact information: Department of Political Science, University of Amsterdam, Oudezijds Achterburgwal 237, Amsterdam 1012DL, The Netherlands. E-mail: e.m.heemskerk@uva.nl.

Meindert Fennema is Emeritus Professor in Political Theory at the University of Amsterdam. He published extensively on corporate elites, political theory, anti-immigration parties, ethnic mobilization, and political violence and authored among other International Networks of Banks and Industry (Martinus Nijhoff 1982) and Is there a Transnational Corporate Elite? (International Sociology 2002). Contact information: Department of Political Science, University of Amsterdam, Oudezijds Achterburgwal 237, Amsterdam 1012DL, The Netherlands. E-mail: m.fennema@uva.nl.

We received valuable input from participants of the elite workshops at the 2nd ISA forum in Buenos Aires 2012 and the Politicologen Etmaal in Amsterdam 2012, as well as from Heleen Mees and two anonymous reviewers. 
female board members of the largest firms in the Netherlands over the period 1969-2011. We show that the female board members do not form a homogeneous group. The first wave of female directors had a political background, the second wave had an academic background, whereas the third wave was recruited from within the corporations. In this third wave, foreign female directors became predominant. Elites open up their ranks and privileged positions to women, but they do so reluctantly and under outside pressure.

\section{Why Are There Suddenly So Many Women in the Corporate Elite?}

Women have recently started to join the boardrooms of large corporations. The share of Fortune 1000 firms that had at least one female board member increased from 11 percent in 1973 to 97 percent in 2006. ${ }^{1}$ Females now take up 16 percent of the board positions available in the USA, followed by South Africa (15.8 percent), Israel and the UK (15 percent), and the Netherlands (14 percent). Only Scandinavian countries score better. Sweden has 27 percent female directors and Finland 24.4 percent. In Norway, the first country to adopt a strict quota system in 2008, 40 percent of board members are now female. ${ }^{2}$ Although female board members remain in the minority, their numbers are steadily growing.

Why and how was it that women were being included in the traditional all-male social circles of the corporate elite? Corporate elites have been all-male bastions for centuries. Only recently are incumbent corporate elites recruiting women. This is happening voluntarily, with the exception of Norway. The inclusion of women needs explanation because it represents one of the major changes during the last twenty years. Our approach is distinct from most scholarly studies on female corporate directors, which are concerned with the question of why there are so few women and the obstacles for larger female representation in corporate boards. We also consider the issue of female board membership as a problem of elite co-optation, and we will unravel the mechanisms through which incumbent corporate elites open up their ranks and privileged positions to women. As we will see, they often do so reluctantly and under outside pressure. Yet, our primary concern is: why and how are women recruited at all?

Following Alexis de Tocqueville, we consider a female presence in corporate boards as a democratization of elite social networks. ${ }^{3}$

1. Alliance for Board Diversity, Women and Minorities.

2. Catalyst, Women on Board.

3. Tocqueville, Democracy in America. 
We define societal democracy as the outcome of equal opportunity and open recruitment. If the group of board members of the largest corporations is a demographic representation of the population at large we call this, following Hanna Pitkin, descriptive representation. ${ }^{4}$ Hence, the more board members are recruited from all groups in society, the more democratic that society is in terms of descriptive representation. Lack of descriptive representation is a sign of elite closure. ${ }^{5}$ Such a lack of descriptive representation in the boardroom has for instance been noted with reference to ascriptive characteristics of board members such as membership in the nobility or in patrician families. Yet, the most blatant deficiency in descriptive representation was the complete absence of female members until the last quarter of the twentieth century. We will consider the increase of descriptive representation as a form of elite democratization. The question we ask here is how an incumbent corporate elite allows the democratization of its ranks.

The issue of female board participation remains contested. Recently, EU commissioner Viviane Reding pleaded for the enforcement of a Europe-wide quota that would require women constitute 40 per cent of the supervisory boards of publicly traded companies by 2020. The opposition to this proposal was both broad and fierce. German Minister Kristina Schröder responded: "I think it is absurd to impose a uniform quota on very different companies... On the surface, a quota may stimulate fairness, but it tends to exacerbate unfairness for individuals rather than eliminate it." On a more personal note she adds "I once benefited from a quota, namely when my party sponsored me as a candidate for the Bundestag in 2002. People still smugly hold this against me today, as if my abilities hadn't counted at all at the time. Many [women] have had the same experience.”6

In Schröder's response, two reasons for championing female board participation surfaced. Building on the natural rights discourse, an equal rights argument appears. Women should be equally present in positions of power because women are equal to men and this is their right. Much more common in the contemporary literature, however, is a functionalist argument. Here, female participation is important because men and women are different. Females bring specific female characteristics to the boardroom that will positively influence firm performance. Schröder in part owed her position in the Bundestag to an imposed quota but felt uncomfortable about this because quotas' coercive nature diminishes the legitimacy of her presence in the

4. Pitkin, The Concept of Representation.

5. Heemskerk and Fennema, "Network Dynamics."

6. Pfister and Schult, "Gender Quota Debate." 
Bundestag. Her argument focuses on individual achievement and merit. We propose a third perspective. We understand female participation on corporate boards as a form of elite co-optation. This focus on the "demand side" of board diversity allows for new insights into the processes that led to more diversified corporate boards and more democratic institutions of corporate governance. We postulate that the route to the democratization of elites in society is generally paved by the state and will argue that this is also true for the corporate elite. Females found their way into corporate boards in different ways. Initially, they obtained seats on government-controlled firms. This exemplifies an exogenous democratization of the corporate elite imposed by the political elite and is typical for the 1970s. Statecontrolled firms served as bridgeheads for female politicians to enter the corporate elite. Once their presence became more accepted, they spread to other businesses as well. By the mid-1990s, reluctant support for female inclusion emerged among the corporate elite, which led to increased democratization from within.

One caveat is in order. Comparing countries in terms of female board membership is somewhat hampered by the existence of different governance structures. Most countries have a one-tier board with both executives and outside members. Elsewhere the executive and supervisory board are two separate entities. Note for instance that the 14 percent of female board members in the Netherlands reported by Catalyst refers to supervisory boards of the largest firms (see figure 2), while the 16 percent in the USA refers to both executive and nonexecutive board members. We are interested in both roles: female board members who serve as executives and/or as outside (supervisory) directors. We will refer explicitly to these different types of directors. At the same time, we restrict our attention to the top decision-making bodies: the corporate boards. This means that the top management team under the level of the board is not taken into account.

We proceed as follows. The next section critically examines the literature on female board membership along the lines of the functionalist and equal rights arguments. Building on this discussion, we suggest a perspective on female board participation as elite democratization. We examine our expectations for the case of the Netherlands, discuss its particular institutional setting, our methods, and data collection, and then analyze our original dataset of female board members over the past fifty years. We focus on the initial entry of female board members, their professional background and shifting recruitment patterns, the position of females in corporate networks, and the role of internationalization. We will show that the state initially induced female board membership and that subsequent internationalization did play an important role for promoting female presence in 
boardrooms. To the extent the traditional corporate elite opens boardroom doors to females, they do so rather reluctantly.

\section{The Functionalist Argument}

Those who favor diversity in boards typically see the recruitment of females as a "strategic necessity." If women are different, they can make a specific contribution to corporations. The question has spurred a large body of empirical research that tries to discover whether and how males and females are different. Recently, a multilevel analysis of a large US dataset shows that there is indeed a large and robust difference between male and female personalities. Females score higher on sensitivity, warmth, and apprehension; men score higher on emotional stability, dominance, rule consciousness, and vigilance. The authors found an unexpectedly large effect, "corresponding to an overlap of only 10 percent between male and female distributions." ${ }^{8}$ Other research has shown that, on average, women are more risk averse than men. ${ }^{9}$ Especially after the banking crisis, some commentators suggested that more women on boards could have prevented much of the damage done by the excessive risk taking of the big banks. In addition, women are found to be trustworthy and to have a more collaborative style. ${ }^{10}$ Another line of argument for the divergent contributions of men and women refers to different life experiences, which causes women "to consider a wider range of options and solutions." 11

The functionalist argument not only states that males and females are different. It also posits that these distinctions make a difference. ${ }^{12}$ This implies that female membership on corporate boards has (or will have) an impact on the performance of the organization. If this is indeed the case, there is a "business case" for the inclusion of women. Female participation on corporate boards is the "smart" thing to do, not just the "right" thing to do. So far, however, scholars have been unable to show a robust relationship between board diversity and firm performance. In their exhaustive analysis of S\&P 500 firms over the period 1998-2002, Carter et al. found no significant effect whatsoever of female board membership on the financial performance of

7. Langevoort, "Puzzles,” 841.

8. Del Giudice, Booth, and Irwing, "The Distance between Mars and Venus," 4.

9. Jianakoplos and Bernasek, "Are Women More Risk Averse?"

10. Heminway, "Sex, Trust, and Corporate Boards"; Croson and Buchan, "Gender and Culture."

11. Fairfax, "Clogs in the Pipeline," 590.

12. See for an overview Rhode and Packel, "Diversity on Corporate Boards." 
firms (Tobin's $\mathrm{Q}$ and return on assets [ROA]). ${ }^{13} \mathrm{~A}$ similar study by Campbell et al. considered the effect of female board membership on the financial performance of Spanish firms (Tobin's Q). ${ }^{14}$ Contrary to Carter et al., they did find a significant and positive effect. In addition, they showed that the effect does not run the other way: profitability does not affect female board participation. Yet Adams and Ferreira found that female board membership in US-based firms had a negative effect on Tobin's Q and ROA. ${ }^{15}$ Here, we have three studies that all used large datasets and advanced methods to study the effect of diversity and came up with very different results. This outcome is emblematic of the entire literature and leads us to conclude that empirical evidence for the business case for female board participation is mixed at best.

These inconsistent research findings are in line with a broader shortage of evidence for a direct relationship between board composition and firm performance. ${ }^{16}$ Studies that attempt to establish a relationship between performance and board composition typically use a simple input-output model where "great inferential leaps are made from input variables such as board composition to output variables such as board performance with no direct evidence on the processes and mechanisms, which presumably link the inputs to the outputs." ${ }^{17}$ In response to this sort of criticism, some scholars have tried to pinpoint mediating variables. Miller et al. for instance investigated how gender and ethnic diversity indirectly influence profitability through affecting innovation and reputation. ${ }^{18}$ Their results showed that both female board membership and racial diversity have a positive effect on innovation, which in turn positively affects firm performance. But, whereas racial diversity also affects reputation positively, they did not find evidence that female board membership does the same. A recent study argued that in the USA, women have as yet had no positive effect on firm reputations. ${ }^{19}$

Despite a huge research effort, there is still no clear "business case" for the inclusion of women on corporate boards. That is, the relation between female board membership on corporate boards and abstract notions of organizational performance (Tobin's Q, ROA) are statistically weak, inconsistent, and case specific. The reason for the lack of strong evidence is not necessarily that diversity does not matter, it

13. Carter et al., "The Gender and Ethnic Diversity."

14. Campbell et al., "Gender Diversity in the Boardroom."

15. Adams and Ferreira, "Women in the Boardroom."

16. Schmidt and Brauer, "Strategic Governance"; Dalton et al., "Meta-analytic Reviews."

17. Pettigrew, "On Studying Managerial Elites," 71.

18. Miller et al., "Demographic Diversity in the Boardroom."

19. Ibid. 
may very well matter a great deal. But without a good sense of what is going on within corporate boards, such a relationship is difficult to establish.

Another functionalist argument for the inclusion of women on corporate boards is that it increases the quality of the decision-making process and board effectiveness. In theory, board diversity can be beneficial as well as detrimental for board effectiveness. On the one hand, diversity broadens the set of information and skills that boards have at their disposal. Groups that are diverse in composition will consider more alternatives and will be more careful to evaluate alternatives. This adds to the quality of decision making in uncertain environments and decreases groupthink. ${ }^{20}$ However, diversity can also arouse negative emotions and lead to higher levels of relational conflict. Since board effectiveness is conditioned by "the boards" ability to continue working together, as evidenced by the "cohesiveness of the board," this may create problems. ${ }^{21}$ Diversity improves the quality of group decision making but may also create interpersonal conflicts. ${ }^{22}$ In sum, there is no compelling empirical evidence suggesting that incumbent corporate elites have an economic incentive to recruit women for their boards. Overall, the functionalist argument fails to provide an empirical underpinning for its most central claim: that taking females on board has direct implications for firm performance.

\section{The Equal Rights Argument}

The equal rights argument builds on moral and social justifications for diversity. It is "the right thing to do" because it aims to rectify existing inequalities that stem from forms of discrimination. ${ }^{23}$ Demands for equal rights and equal participation for men and women became widespread and highly visible during the French revolution, when equality became a buzzword in politics. Most feminist demands were based on natural rights. This is clear in the preamble of the Declaration of the Rights of Women and the Female Citizen, formulated by Olympe de la Gouges in 1791. Lack of respect for these rights are "the sole cause of public disaster and of the corruption of government." ${ }^{24}$ It is particularly directed at abolishing barriers to entry based on sexist prejudice

20. Janis, "Groupthink."

21. Forbes and Milliken, "Cognition and Corporate Governance," 492.

22. Erhardt, Werbel, and Shrader, "Board of Director Diversity," 102.

23. Fairfax, "Board Diversity Revisited," 856-7; Wilkins, "From 'Separate Is Inherently Unequal'."

24. De Gouges, "Declaration of the Rights of Woman and Citizen." 
and discrimination. Such universalism abstracts from the particularities of concrete human beings and hence considers gender differences irrelevant to the rights to elect and to be elected. Yet even De Gouges refers to gender differences and speaks of her own sex as the one that is "superior to the other in beauty and courage, shown in the cavalry of motherhood." ${ }^{25}$ A contemporary supporter of equal rights for women, the Marquis de Condorcet, attributed such differences to culture rather than biology. According to him, "it is just as reasonable for women to care for physical beauty as it was for Demosthenes to care for his voice and gestures." ${ }^{26}$ It is the position of women in society that accounts for being different. Of course physical differences exist, but they become less relevant in modern society. And besides, Condorcet argues polemically, physical differences are considered relevant in the case of women, whereas the same differences are not considered relevant when discussing men. "If physical weakness were to be reason not to grant voting rights to women, they should not be granted to men who suffer from gout." ${ }^{27}$ Condorcet clearly embodied the equal opportunity discourse, where differences between men and women are predominantly determined by male prejudice and culture and hence can, and should, be eliminated.

The equal rights argument precedes the functionalist argument and builds on a universalist assumption. However, in recent years, a functionalist argument for female board participation became increasingly popular, notwithstanding its weak empirical underpinnings. But why then does a corporate elite slowly but steadily open its realm to outsiders? Through which channels did women find entrance to the highest level of corporate decision making? We suggest two routes: from outside and from inside the corporate elite.

\section{Elite Democratization}

The equal rights argument and the functionalist argument can be related to two different pathways that lead to female board participation and hence elite democratization. Females can gain access to the corporate elite through acceptance from within the corporate elite because it seeks more diversity or through pressure from outside the corporate elite, because excluding women is a form of discrimination.

To start with the latter, the equal rights argument for female participation in corporate decision making is essentially a normative and

25. Ibid.

26. Condorcet, La Politique De Condorcet, 165-6.

27. Ibid. 
political one. Political parties actively promote more equal opportunities for women. However, political elites have limited power to control corporate elites. While it is within the former's power to regulate corporate board membership, this has become difficult in a society where (neo)liberal values and conceptions of states and markets dominate. The role of the state is increasingly seen as setting the "playing field" and guarding some basic rules, but it is not to intervene in the operations of corporations. Indeed only the Norwegian parliament so far has set a mandatory quota for female board membership (although very recent developments in France and Belgium try to follow that example). This does not mean, however, that parliaments do not exert pressure by establishing targets. We expect that the effect of political pressure is highest where the political elite has some leverage over the economic elite. This implies that the initial entry point of females on corporate boards would be in corporations within the state's sphere of influence. State-owned corporations are an extreme example of this.

But female membership can also be induced from within. An important quality of well-functioning elites is the capacity to incorporate homines novi. By inviting successful up-and-coming people, the incumbent elite refreshes its talent pool and sets of expertise. Perhaps more important, inviting the promising to join their ranks is a pre-emptive strike in order to avoid a build-up of power outside the incumbent elite's sphere of influence. This is a strategy of co-optation that elites throughout history have successfully applied. ${ }^{28}$ Also, they typically recruit members from other, emerging elites. In this way, they effectively create weak ties ${ }^{29}$ or bridges ${ }^{30}$ to other social networks. For these reasons, successful elites are often willing to invite outsiders into their midst, although these invitees are typically not regarded as genuine members. ${ }^{31}$

An obvious problem for female recruitment is that female entry can still be considered an elite-threatening action for at least three reasons. First, there may exist a collective interest of men who do not want to share their "old boys network" benefits with (female) outsiders. Secondly, the male group of board members may overlook the specific set of skills and personality traits that women can bring to the boardroom. Instead, they would rather recruit new members similar

28. See for instance Fleron, "Cooptation as a Mechanism of Adaption to Change" for co-optation in USSR elites; and see Richardson, Kakabadse, and Kakabadse, Bilderberg People for co-optation patterns in modern day global elites.

29. Granovetter, "The Strength of Weak Ties."

30. Burt, "Structural Holes and Good Ideas."

31. See Richardson, Kakabadse, and Kakabadse, Bilderberg People for a number of illustrative examples. 
to themselves in appearance and outlook. This is the well-known principle of homophily. ${ }^{32}$ Thirdly, there is a "traditionalist" argument that has received some empirical support and is popular in many corporate elite circles: the introduction of females to the boardroom has a negative effect on the performance of male members because their presence would distract the males from focusing on their board tasks. By having a woman on the board, the entire group dynamic of an old boys social club would change into a social arena where male board members compete for the attention of the female member(s) (for similar reasons, no females were allowed to set foot on the trading floor of the Amsterdam stock exchange until 1975). As a result, top managers and board members look alike; they are typically educated at the same institutions, attend the same social clubs, and are with few exceptions male. ${ }^{33}$ As Tocqueville already noted, social homogeneity unsettles social control because "when conditions are unequal, no inequality, however great, offends the eye. But amid general uniformity, the slightest dissimilarity seems shocking, and the more complete the uniformity, the more unbearable it seems." ${ }_{34}$ In this situation, the corporate elite tries to defend its privileged position against newcomers while at the same time feeling some need to adapt to changing societal circumstances in order to maintain its position.

Regarding the inside pressure that exists among the "old boys," we expect that high status boards are different. High status confers esteem and privilege. ${ }^{35}$ Boards and directors with higher status can be expected to have a higher degree of freedom to deviate from standard practice. ${ }^{36}$ Therefore, we expect that high status boards are more inclined to allow females to join. Within a social network such as the corporate elite, status is generally operationalized with some measure of network centrality. Or as Podolny argues, status "flows through associations" and represents how "location within a hierarchy... determines the opportunities and constraints." ${ }^{37}$ Boards with central positions in the social network of the corporate elite are therefore more likely to invite females among their midst.

Table 1 gives an overview of the two pathways to board democratization. We expect that democratization is initially endorsed through

32. McPherson, Smith-Lovin, and Cook, "Birds of a Feather."

33. Greve and Mitsuhashi, "Power and Glory"; Domhoff, The Higher Circles; Domhoff, The Bohemian Grove and Other Retreats; Barnes, "The Organizational Mosaic of U.S. Corporate Directors"; Westphal and Khanna, "Keeping Directors in Line."

34. Tocqueville, Democracy in America, 364.

35. Washington and Zajac, "Status Evolution and Competition."

36. Ibid; Centola and Macy, "Complex Contagions and the Weakness of Long Ties."

37. Podolny, Status Signals, 11, 14. 
Table 1 Elite democratization from within and from outside

\begin{tabular}{|c|c|c|}
\hline & \multicolumn{2}{|l|}{ Democratization from } \\
\hline & Outside elite & Within elite \\
\hline Change comes from & $\begin{array}{l}\text { Pressure from outside } \\
\text { the elite }\end{array}$ & $\begin{array}{l}\text { Pressure from inside the } \\
\text { elite }\end{array}$ \\
\hline Inspired by & Equal rights argument & $\begin{array}{l}\text { Functionalist and equal } \\
\text { rights arguments }\end{array}$ \\
\hline First movers & $\begin{array}{l}\text { Firms within the sphere of } \\
\text { influence of the state }\end{array}$ & High status firms \\
\hline $\begin{array}{l}\text { Professionals } \\
\text { background of } \\
\text { female directors }\end{array}$ & Politics & Business \\
\hline Timing & $\begin{array}{l}\text { Precedes democratization } \\
\text { from within }\end{array}$ & $\begin{array}{l}\text { Follows democratization } \\
\text { from outside }\end{array}$ \\
\hline
\end{tabular}

state pressure. Firms within the sphere of influence of the state will be most likely to be affected by this. The inspiration comes from the equal rights argument. Democratization from within the corporate elite, on the other hand, stems from the conviction of the incumbent elite that it is smart to invite females into their ranks. This can be inspired by the equal rights, the functionalist argument, or, typically, a mixture of both. We expect the first movers to be high status firms with an international orientation.

Before we proceed to the Netherlands case, we should note that in our discussion, we emphasize the "demand side" of female board participation. On the "supply side," there are ample barriers as well. First, until recently women were also strongly underrepresented in management positions just below the board level. ${ }^{38}$ Indeed an oftenheard excuse for the lack of female board members is that there are few qualified candidates. For instance, Aad Jacobs, former president of Dutch bank-insurance conglomerate ING, declared that "he had never met a woman qualified to become a board member." ${ }_{39}$ But if the implicit quality that he searches for is maleness, it may indeed be difficult to find well-suited directors. A second supply side barrier to women entering the corporate elite is that management experience in other segments of society does not seem to count in the corporate recruitment process. This means that it is difficult to switch from public administration to business or from the nonprofit sector to business. Third, women often prefer part-time jobs, as is the case in the Netherlands. ${ }^{40}$ This desire, however, should not inhibit women from entering a supervisory board—which is a part-time occupation-but

38. Sociaal en Cultureel Planbureau, Emancipatiemonitor 2012, 2013.

39. Fennema and Heemskerk, Nieuwe Netwerken, 95.

40. Visser, "The First Part-Time Economy in the World." 
it does make women reluctant to enter the executive board. In what follows we devote our attention mainly to the demand side and less to the supply side. The main reason for this is not that we believe the demand side is more important, but that our contribution lies in the particular perspective we offer on this aspect of female board participation.

\section{Business Elites in the Netherlands}

The incorporation of female directors into Netherlands' boards of directors over the period 1969-2011 serves as our research setting. A small yet highly internationalized economy, the Netherlands scores above average in recent rankings of female membership on corporate boards. The size of the Dutch business community is such that we were able to fully map the dominant corporate elite and trace the professional background of all female board members of the largest firms in the Netherlands over the period 1969-2011. Before we report these empirical findings, we will first sketch the historical and institutional particularities of the Dutch business community.

The Netherlands' corporate elite remained all-male up until the start of the twenty-first century. Other elites opened their ranks to women in the second half of the twentieth century, such as the political elite (1970s), state bureaucrats (1990s), and the semi-public sectors (1990s). ${ }^{41}$ The corporate elite, however, was able to restrict considerable female entrance until the late 1990s. In the neo-corporatist landscape of the postwar Netherlands, corporate governance developed a stakeholder orientation. This built on the notion that there should not be one stakeholder within the firms whose interest dominates over the others, such as, for instance, the shareholder. During the early 1970s, this was formalized in corporate law. The Netherlands has a two-tier board system, where inside directors convene in the executive board, and outside directors meet in a separate supervisory board. The supervisory board was defined as an independent council with the task of serving "the interest of the limited liability company and its enterprise," rather than shareholder interests alone. State-controlled corporations in the Netherlands typically functioned at arms-length from political administrations as semi-private firms. ${ }^{42}$ Their governance structure mimicked corporations with executive and supervisory directors. A more shareholder-oriented governance perspective has gradually replaced the stakeholder orientation. Today, both a

41. Fennema and Schijf, "Elites in Nederland."

42. Heemskerk, Mokken, and Fennema, "The Fading of the State." 
one-tier and a two-tier board structure are allowed, although the latter remains dominant.

In the procedure for recruiting new directors, the supervisory board plays a crucial role. In the traditional Dutch corporate governance system, it is the supervisory board that selects and appoints new executive board members. And because the supervisory board is considered an independent body, it appoints new supervisory board members as well. Only recently, shareholders gained more influence on the recruitment procedure. Dutch board recruitment practices resulted in a postwar "Old Boys Network." A notable effect was a dense network of board interlocks. When a person sits on the board of at least two firms, he or she creates an interlocking directorate. These board interlocks are important building blocks for the business community. ${ }^{43}$ Not only was it a male-only community, but many of the "big linkers" in the network were recruited from aristocratic families. ${ }^{44}$ In this period, females were fully excluded from` corporate boardrooms.

The second feminist wave in the Netherlands started during the seventies. But this feminist movement came from the left and hence had a strong bias against capitalist business organizations. Women were mobilized to demand representation in the political arena and equal rights on the labor market, but not to press for female representation in the boardroom. Yet, the feminist movement did indirectly affect corporate elite recruitment. The first business school in the Netherlands, Nyenrode, was forced to open its doors to female students in 1976. Old aristocratic student fraternities that traditionally provided business leadership were also "emancipated" in the seventies. Hence, pathways to economic elite positions slowly opened up. The feminist movement that had been so strong in the 1970s ran out of steam in the 1990s, but it did not disappear. Instead it was just mainstreamed and thus lost its radical left-wing character. The demand for female board participation in large firms now slowly became part of the feminist agenda. This pressure further mounted after 1989 when communism collapsed. Liberalism turned out to be the historical winner but was at the same time challenged to live up to its own program that once included equal rights for men and women. We may add that early feminism had induced women students to pursue a career rather than become housewives. Thus, by the nineties, there were many women in professional careers, within which was a group of female professionals and managers realizing that further

43. Carroll and Fennema, "Is there a Transnational Business Community?"; Scott, Corporate Business and Capitalist Classes; Heemskerk, Decline of the Corporate Community.

44. Heemskerk and Fennema, "Network Dynamics," 807-32. 
career advancement was apparently blocked at the highest levels of management. The so-called "glass ceiling," also felt within the universities where females hardly ever became full professors, became a discussion topic in the newspapers. It became a political issue and hence, also a problem to be tackled by the corporate elite.

In the debate on corporate governance, female board participation did not become an issue until the twenty-first century. The first Dutch good governance code (Commissie Peters), implemented in 1996, did not address the issue of board composition at all. After some corporate fiascos and scandals, most notably the near bankruptcy and accounting scandal of Ahold in 2003, a new and more stringent governance code was introduced. This Tabaksblat code (2004) did not include references to diversity in the supervisory board either. But, while the corporate elite did not seem concerned with the low number of female board members, the issue slowly became more politicized. In 2006, a lobby organized to push for more females on the corporate boards under the header of "women on top." This call for more females on corporate boards was inspired by the presumed waste of human capital, a necessary increase in workers' participation (setting a good example), and ultimately also by the business case argument. Disregarding the diverse results of previous studies, activists claimed that corporations with more female top managers outperformed other firms. ${ }^{45}$ They did not campaign on an equal rights argument. A year later, in 2007, their lobbying resulted in a parliamentary motion that called for a target for the number of females on corporate boards. The updated Dutch corporate governance code stated that a company should "aim for a diverse [board] composition in terms of such factors as gender and age." ${ }^{46}$ Later, the Labour Party succeeded in passing a law that presses large corporations to have a target of 33 percent female board members. An indication of the issue's increasing salience in the public debate is illustrated by figure 1. It gives an admittedly rudimentary overview by counting for each year after 1990 the number of Dutch newspaper articles that included both the word "females" and "executive board" or "supervisory board." The overall trend is clear and corroborates the notion that public discussion on female board membership only picked up early in the twenty-first century.

The growing attention to female board participation was not without effect. Figures 2 and 3 illustrate the entry of women onto the Dutch supervisory and executive boards of the largest 25, 100, and 500 corporations (as reported by the Sociaal Cultureel Planbureau).

45. Mees and Kroes, "Meer Vrouwen Aan De Top - Desnoods Verplicht." 46. Lückerath-Rovers, "Women on Boards and Firm Performance." 


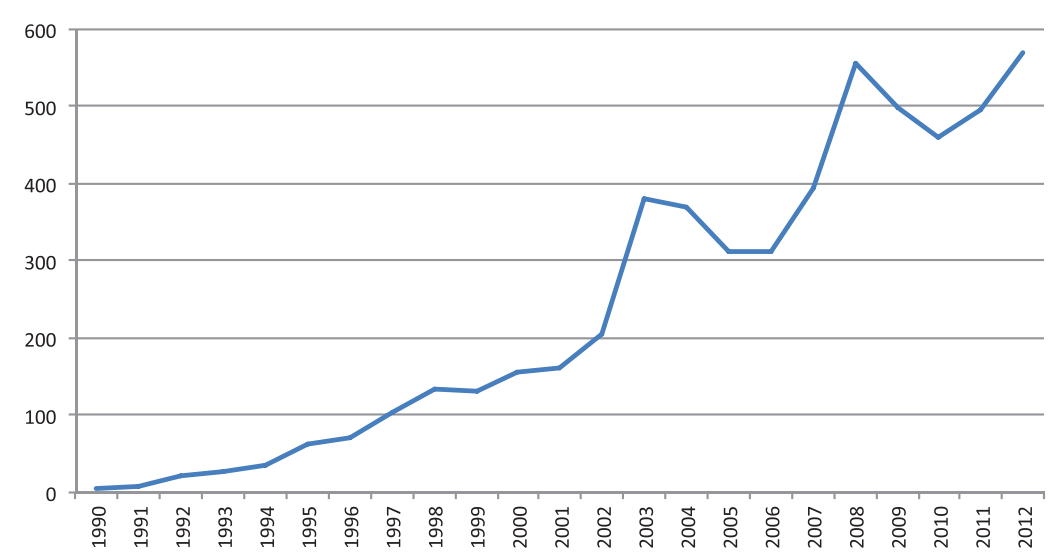

Figure 1 Dutch Newspaper articles that mention females and executive board or supervisory board. All Dutch national distributed newspapers are included. Source: Lexis Nexis Academic.

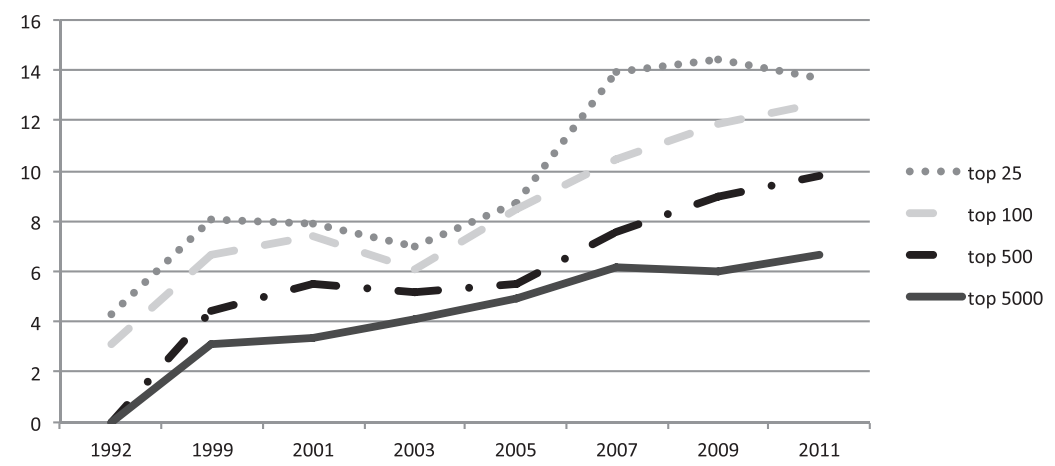

Figure 2 Percentage of females on Dutch Supervisory Boards. Source: Emancipatiemonitor 2012, 2000, Sociaal en Cultureel Planbureau.

As expected, in 1990, females were still rarely found. On the executive boards, there were no women at all. In the supervisory boards of the 100 largest firms, women occupied only 3.1 percent of the seats. The figures warrant three observations on women's subsequent inclusion. First, while the largest 25 firms do have the highest number of female supervisory or outside directors (see figure 2), until very recently, they were the least willing to include women on their executive boards (see figure 3). Second, the increase in the number of female directors took place in two waves, separated by a period of consolidation. After an initial period of substantial increase during the 1990s, the rise of female supervisory board members consolidated until 2003/2005, when a second period of rising female board membership commenced. Beginning in 2003, there was a new surge that gained pace from 2005 onward. This increase was strongest among the top 25 firms that had, by 2009, 14 percent female supervisory 


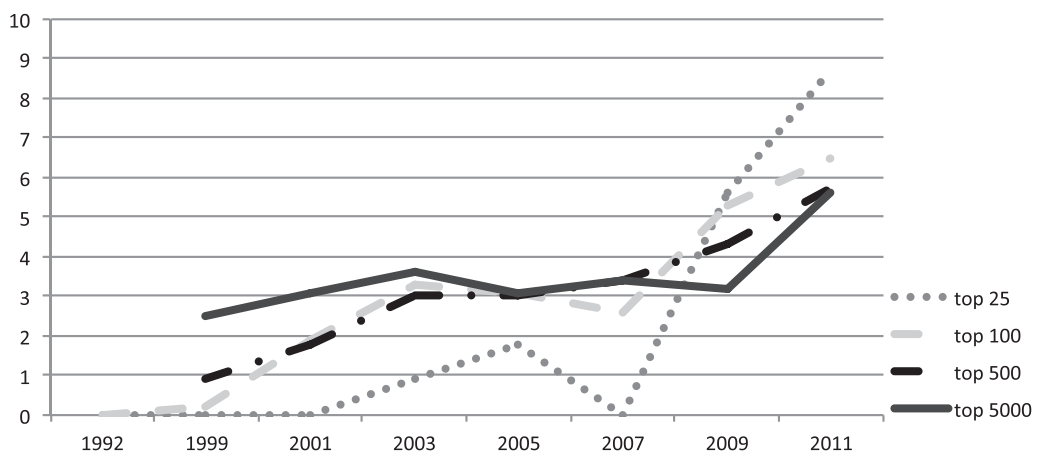

Figure 3 Percentage of females on Dutch Executive Boards. Source: Emancipatiemonitor 2012, 2005, Sociaal en Cultureel Planbureau.

board members. For executive boards, a similar trend is visible, although with a time lag. Thus, between 1999 and 2003, the number of female directors increased steeply, followed by a period of consolidation. Since 2007, the number of female executive board members among the top 100 corporations was again on the rise, up to 6.5 percent in 2011. Third, the timing of the two waves of female ascension to corporate boards mirrors a similar development in Foreign Direct Investment (FDI). Figure 4 shows the increase in Dutch female board members (both executive and supervisory) as well as the FDI trend, which seem to move together. In our analysis, we will therefore have a keen eye for the role of internationalization.

\section{The Construction of the Data}

We traced back the composition of corporate boards for the years 1969, 1976, 1996, 2001, 2006, and 2011. We included both the executive directors at the level of the board (raad van bestuur) and the supervisory directors (raad van commissarissen); top management positions below the board of directors were not added. The dataset was constructed following the common practice of stratified sampling. ${ }^{47}$ Each wave (except 1969, see below) contains the 200 largest industrial and service firms of the Netherlands in terms of total revenue and the 50 largest financial firms in terms of total assets. Both listed and non-listed firms are included. For 1996 and 2001, we used the existing dataset as described and analyzed by Heemskerk. ${ }^{48}$ The 2006 and 2011 networks were compiled for the purpose of this study. Firms without significant economic activities (notably administrative units 


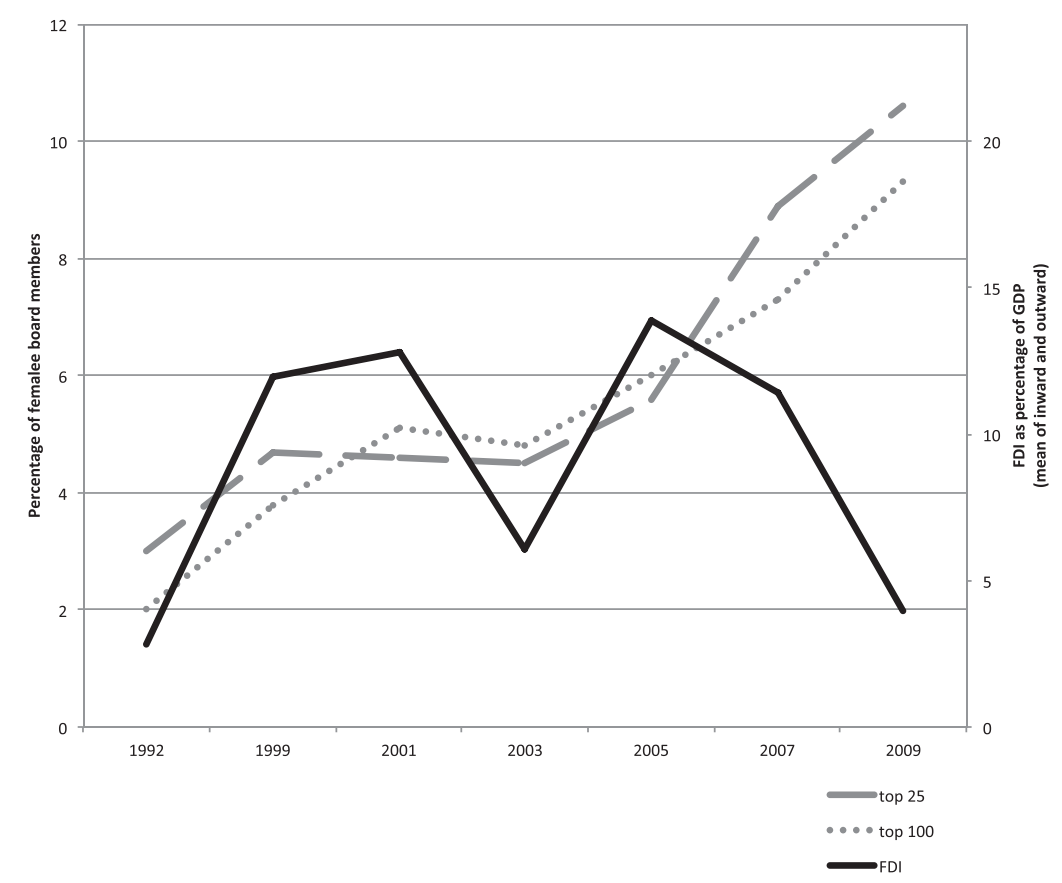

Figure 4 Female board participation and FDI in the Netherlands. Source: Foreign Direct Investment: CIA World Factbook (accessed June 2012). FDI gives the average of inward and outward FDI. Source Percentage female board members: Emancipatiemonitor 2010, 2005, Sociaal en Cultureel Planbureau.

and mailbox firms) are excluded, and subsidiaries of firms that are part of the largest 250 firms are set aside as well. The 1969 dataset comes from the seminal "traces of power" study and contains the largest 84 firms. ${ }^{49}$

Subsequently, we identified all female board members. This allowed us to analyze the proportion of female board directors among the Dutch corporate elite, but to also consider their position within the structure of the network of interlocking directorates. We then collected information on the career background of all female board members in our sample. For each person, we traced her career trajectory through sources such as annual reports, personal websites, newspaper, and magazine articles. For almost all female board members, we have been able to trace professional backgrounds. We differentiated between board members with a career in business (both financial and non-financial), professional services (law, accounting), or academia. For the female politicians who served on corporate boards, we distinguished between those who served on the board of a (former) stateowned or controlled firm and those who did not. Finally, we have a

49. Helmers et al., Graven Naar Macht. 
separate category for those directors who derive their board position from family ownership.

\section{Women on Dutch Corporate Boards}

\section{0s: A Reluctant Entrance}

Tracing the first female presence in the largest corporate boards in the Netherlands takes us to the late 1960s. There were earlier female directors in Dutch firms. Louise Marguérite van Loon for instance joined the prestigious family bank Hope en Co as a partner during the 1920s, alongside her father and several brothers. Such female presence at top levels occurred in family firms mainly, and certainly not on boards of limited liability corporations. The first female board member at the largest firms in the Netherlands was at chemical corporation Akzo (now Akzo Nobel). Mrs. Kittie Schudel-Van Zwanenberg served on the supervisory board from 1969 to 1982. The Dutch business community has always considered Akzo a high status board, in the same league as Philips, Royal Dutch Shell and Hoogovens, with a fair share of aristocrats among its members. ${ }^{50}$ Membership on the supervisory board was typically granted to well-regarded executives from the other largest and most prestigious Dutch firms. As a consequence, Akzo was the third most central firm in the network of interlocking directorates by $1969 .{ }^{51}$ This seems to indicate the plausibility of our expectation that democratization from within is more likely to occur at high status firms. In this case, however, something else was at play. Mrs. Schudel-Zwanenberg's board position was the consequence of family capital. She was the daughter of Saal van Zwanenberg, son of a Jewish family of butchers and cattle traders and founder of the pharmaceutical enterprise Zwanenberg-Organon. During a wave of late 1960s mergers and acquisitions, AKZO acquired Organon (by then Koninklijke Zout Organon [KZO]) in 1969. Schudel-Zwanenberg already served on the supervisory board of $\mathrm{KZO}$ and retained her position when it was merged into AKZO. At AKZO, the separation of ownership and control had not yet fully taken place and the founding families still gained a fair share of influence through board positions. Moreover, in the Van Zwanenberg family, there was no male sibling who could take the board position. Thus, the first female entrance among the most important Dutch corporate boards was derived from ownership.

50. Heemskerk, Decline of the Corporate Community.

51. Helmers et al., Graven Naar Macht, 237. 


\section{0s: The State Steps In}

During the seventies, we see that more women entered corporate boards. In 1976, twelve female board members were identified at the largest 250 firms in the Netherlands (see table 2). In absolute terms, they represented 0.54 percent of all corporate board members. This extremely limited representation shows that female board presence was still an exception, but not unheard of. Among these twelve, nine were politicians, eight of whom served on boards of state-controlled corporations. They sat on the supervisory board ex officio, for instance where positions on regional energy company boards were reserved for aldermen. The democratization of the political elite made these offices increasingly accessible by females as well. This was a spillover effect from one elite to another. Political women who managed to enter the boardrooms did not come from any particular political party. They were Labor party members (three), liberal conservatives (two), and liberal democrats (two). There was even one communist woman director. This heterogeneity in political background suggests that the female board presence did not result from a particular political group's agenda but rather was a general result of an overall increase in women's accession to key political positions. One female politician stands out because she served as supervisory board member of a private firm, the luxury shopping mall Royal Bijenkorf NV. Mrs. Til Gardeniers-Berendsen was a member of parliament for the Christian Democrats from 1971 until 1977, when she became minister and was forced to resign from the board.

Although the number of cases we consider here is small, it does provide us with important information because these were the first women to enter corporate boards. During the 1970s, politicians paved the way. State-controlled firms were the first to place female directors on their boards. Only two out of twelve in 1976 gained positions through capital ownership (including the aforementioned Mrs. Schudel). The final female board member we encounter is more distinctive. From 1976 to 1989, Mrs. Maria 't Hooft-Welvaars served on AMRO bank's supervisory board. AMRO is one of the two largest banks in the Netherlands (the other being $\mathrm{ABN}$ ) and an organizing pillar in the network of interlocking directorates. ${ }^{52}$ What was distinctive about this board appointment is that for the first time, a woman was invited to one of the most important boards in the Netherlands, not for her political affiliations or family background, but for her expertise. She was a well-respected economist and became a professor in Rotterdam when, as rumor had it, she was passed over for a chair in economics at the University of Amsterdam because she was a woman. Before

52. Heemskerk, Decline of the Corporate Community. 


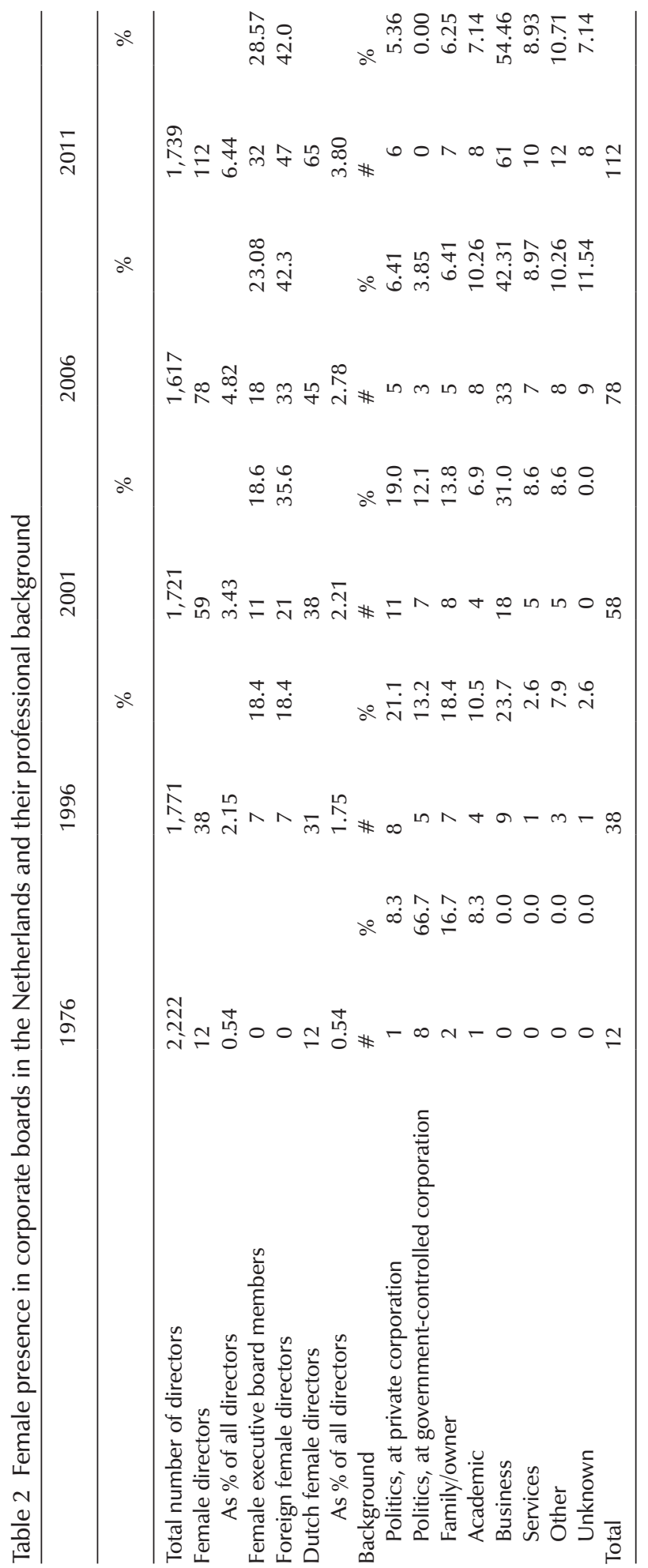


she was seated on the supervisory board, she served three years on the advisory board, together with Mrs. H. G. Goudswaard-Blom, who became lady-in-waiting to Queen Beatrix a few years later. It seems that she made such a good impression and contribution that the board members deemed it fit to invite her to the supervisory board. Perhaps it helped that the CEO of AMRO had some experience with female board participation because he also sat on the supervisory board of AKZO, where he worked together with the aforementioned Mrs. Schudel. This particular case falls into the category of recruitment from within the corporate elite. And as we expected, this occurred at a high status board right in the midst of the elite corporate network.

\section{0s and Mid-1990s: A Widening of Female Presence}

Following 1976, we see that the influx of women onto boards slowly gained pace. By 1996, there were 38 female board members among the largest 250 firms: a meager 2.15 percent of the entire corporate elite. But while the overall numbers do not show spectacular progress, an important change did take place: the first women entered executive boards. In 1996, seven of the thirty-eight female directors held executive positions. None reached the corporate boardroom through politics or family ties. They all had a career in business. Some were entrepreneurs and CEOs of their own companies (Tineke VeldhuisHagedoorn of Holland Colours, Sylvia Toth of Content), others rose through the corporate hierarchy, such as Marielle Wiegmans. Trained as a secretary, she started as a desk clerk at Rabobank in 1984 but soon became a trader. After two years, she left for stockbroker AOT, where she became executive board member in 1996. This example underscores the increased importance of meritocratic recruitment and open career trajectories. By the mid-1990s, meritocratic recruitment practices, in combination with women's increasingly-broad business careers, created a situation where the highest corporate echelons were no longer out of reach.

Politicians were still well represented among the female members of the Dutch corporate elite by 1996, although not as omnipresent as twenty years before. They accounted for almost 35 percent of the female board positions (ten years later, the share of female politicians would significantly decrease). In contrast to the 1970s, however, the female politicians were increasingly invited to corporate boards that were outside the state's sphere of influence. Businesses such as retailer Vendex (formerly Bijenkorf), publishers VNU and PCM, but also financials, such as Rabobank and Generale Bank, invited female politicians onto their supervisory board. This gradual acceptance of women also led to their ascension within the network of interlocking 
directorates. In 1996, six female directors had more than one board position among the largest 250 firms. We call members of the corporate elite with at least four board positions big linkers. ${ }^{53}$ In the mid1990s, only one female was a big linker (vs. 47 males). Neelie Kroes came from a Rotterdam business family and while she received a masters in economics, she chose a career in politics. In 1971, she became a member of parliament for the Liberal Conservatives (VVD), becoming a member of the government from 1977 to 1989. She is a prime example of a female politician who was invited onto supervisory boards during the 1990s. Kroes acquired positions at firms such as Ballast Nedam (1990), McDonalds Nederland (1991), Nationale Investeringsbank (1991), Nederlandse Spoorwegen (2002), and many others. From 2004 onward, she continued her political career as European Commissioner. She was also an open supporter of the lobby for more female board participation that emerged early in the twentyfirst century.

The democratization of the corporate elite also continued in the more traditional parts of the business community. There was an increase of female board members with a family or ownership relationship to the corporation. This signals a transformation in which male members of a family no longer exclusively hold the supervisory positions that safeguard family investments. Take for instance, the longstanding leaders in Dutch industry and trade, the Fentener van Vlissingen family. In the late twentieth century, it was led by brothers Paul and Frits. By 1996, the family relied on Annemiek Fentener van Vlissingen (Frits' daughter) and niece Marguerite Mautner MarkhofCassis Farone (Paul's niece) to oversee family interests through board positions. "In the family it was custom to keep the women out of the firms," Paul reflected in an interview. "When my grandfather died, his daughters did not inherit any of the shares of SHV [the family company]; that would have been an unspoken invitation to the son-in-law to come and work with the firm. My brother and me, we changed this for our children." ${ }_{54}$ Here, we see a clear example of democratization from within the corporate elite inspired by an equal rights argument.

A final note on the background of female board members by the mid-1990s concerns a modest increase in female board members with an academic background, such as G. M. Van Rosmalen, professor at Delft Technical University and supervisory director at Holland Colours; Dr. Hommes, professor in social sciences and member of the board of insurance firm Delta Lloyd; Professor Van der Berghe who

53. Heemskerk and Fennema, "Network Dynamics," 807-32.

54. Haasnoot, "Ondernemer Paul Fentener Van Vlissingen." 
became member of the board of Bank-insurance firm ING in 1991; and professor at Nyenrode business university Roobeek, supervisory director at publisher PCM and financial conglomerate Fortis. The corporate elite started to recruit females from the academic elite.

At the dawn of the twenty-first century, women gained more ground in the corporate elite; their numbers grew. Some reached top executive positions as well. Yet, it is striking to see that even by 2001, fewer than one-third of the female board members had a distinct business background. The incumbent corporate elite preferred females from other elites on their boards, such as politicians and academics. In the boardroom, women encountered a dominant male faction with business profiles. The influence of the female partition of the corporate elite is therefore not only limited by their small numbers, but also by their non-business background, which made them more "visitors" than full-fledged members of the elite. Such a strategy-inviting women from non-business elites-allowed the incumbents to democratize their ranks without giving up a dominant position.

\section{The Twenty-First Century: Competition With Foreigners Grows Stronger}

Female representation at the apex of corporate power steadily increased after 2001, now featuring female board members from business and professional services such as accounting and law. Their number steadily increased, from 59 in 2001, and 78 in 2006, to 112 in 2011. This, at the last date, equates to about 6.5 percent of all board members. However, a closer look reveals a striking observation that suggests that the increased numbers are not necessarily good news for Dutch females. As it turns out, Dutch corporations increasingly recruit foreign female directors to their boards.

Internationalization of board composition markedly increased over the past decade, in particular among the largest listed firms. The Netherlands in particular stands out with a relatively high number of non-nationals as board member of the largest listed firms. ${ }^{55}$ Merger and acquisition activities of Dutch corporations have been an important reason for the large overall influx of foreigners, both male and female. ${ }^{56}$ But what is striking is that the share of foreign female directors is several magnitudes higher than the foreign male directors. In 2001, 21 of the 59 female board members came from outside the Netherlands. For those among the group of female directors with a business background, the contrast is even stronger. Only five out of

55. Van Veen and Marsman, "How International Are Executive Boards."

56. Heemskerk, "De Internationalisering van de Nederlandse Financieel Economische Bestuurselite.” 
the total eighteen are Dutch. This leads us to the observation that the inflow of female directors that takes place is only partly a sign of the emancipation of the Dutch "old boys" network. Indeed, as a Dutch female, it is still very difficult to reach a top position, and now even more so because of the popularity of foreign females.

Some of the foreign female board members serve on "genuine" Dutch firms, such as big linker Lutgart van den Berghe at ING, CSM, SHV, and KLM; Toni Rembe at Aegon; and Nancy McKinstry who became the first Dutch female CEO of a major stock listed firm when she took over leadership of publisher Wolters Kluwer in 2003. Before she had been CEO of US-based publisher CCH and joined the board of Wolters Kluwer when it acquired CCH. However, we see that a fair share of female board members actually serve on the boards of foreignowned or -controlled firms, take for instance Patricia Barbizet-Dussart at Gucci Group and Miuccia Prada Bianchi at Prada Holding (in 2001). Both firms are listed and based in the Netherlands but should not be seen as genuine Dutch companies. The relocation of head offices and the increase of international mergers and acquisitions bring foreign women onto corporate boards, but it inflates the figure of female presence in Dutch corporate boards. This is an important caveat that remains disregarded in the common literature on nationality diversity on corporate boards.

After 2001, the share of foreign female directors increases to over 40 per cent of all female directors in 2006 and 2011. Out of the 112 female board members in 2011, only 66 have Dutch nationality (see table 2). And those females with a career in business increasingly achieve executive board placements as well. By 2006, there are eighteen female executive board members, and five years later, this has increased to thirty-two. About half of them are foreigners, either at foreign-controlled or at "genuine" Dutch firms. And the rest have Dutch nationality. When we look at the professional background of the Dutch and the non-Dutch female board members, we see marked differences. Figure 5 shows the differences in background for the female board members in 2011. Of the Dutch board members, 40 per cent have a business background. However, for the foreign directors, this is no less than 75 per cent.

A closer look at the group of Dutch female executives leads to another interesting observation. Many Dutch female executives hold their position in firms that are former state-controlled or stateowned firms. There is Carlo Smits-Nusteling at KPN and Merel van Vroonhoven at the Dutch Railways, Claudia Zuiderwijk at ProRail (ad interim), Mirjam Sijmons at Eneco, and Caroline Princen at ABN AMRO, which became a state-owned firm after the bailout following the financial crisis. Some Dutch females reach top executive positions 


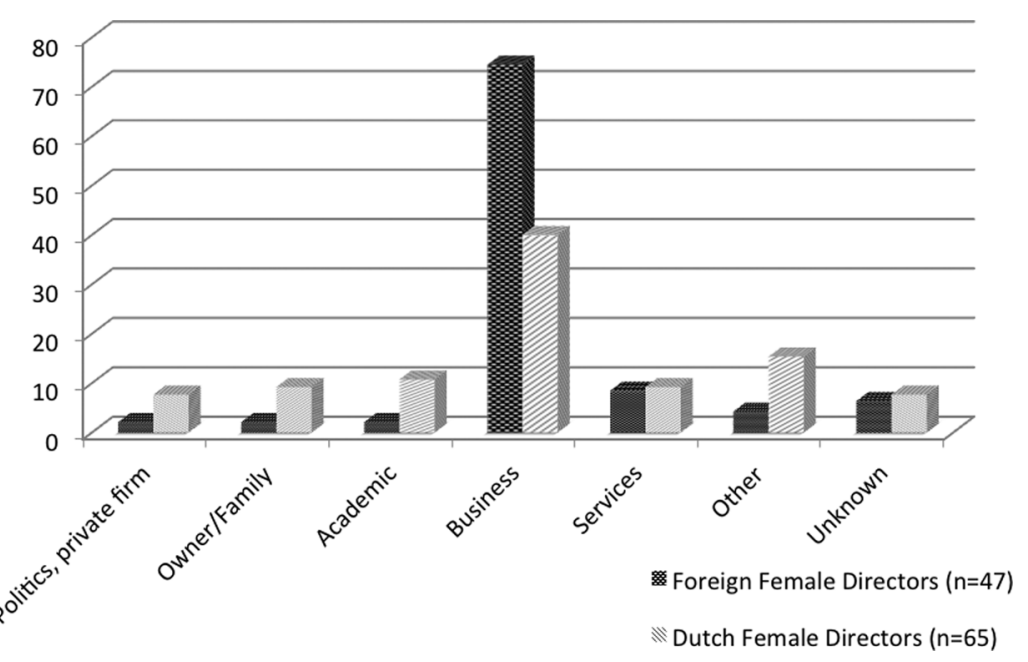

Figure 5 Professional background of Dutch and non-Dutch female directors in 2011.

at other firms as well (for instance Jolanda Poots-Bijl at Volker Wessels Stevin and Gerlinde Silvis at Rabobank), but the numbers suggest that the firms that are or used to be within the sphere of influence of the state are still more willing to recruit females into their top echelon.

\section{How the Old Boys Open Their Ranks to Women Without Losing Their Power}

In the twenty-first century, female corporate board members are no longer an exception. In absolute terms, their numbers may still be low compared to the number of male board members. At the same time, a vast share of big business now recognizes that female board membership is an inherent element of the properties of the business community. In the last forty years, the female politicians that first found their way into corporate boards have been replaced by women with a business career trajectory. Figure 6 shows how the professional background of female directors (both executive and nonexecutive) changes over the period 1976-2011. By 2006, no more than 10 percent of the female directors came from politics, and five years later, this dropped to an even lower 5 percent.

Female politicians paved the way for other female board members. Following more meritocratic recruitment practices and career development, females with a business background increasingly enter corporate boards. This also underscores another important observation: the group of female board members is not homogenous but consists of several groups and cohorts. The politicians came first, then came the academic professors and finally the women with a business career. 


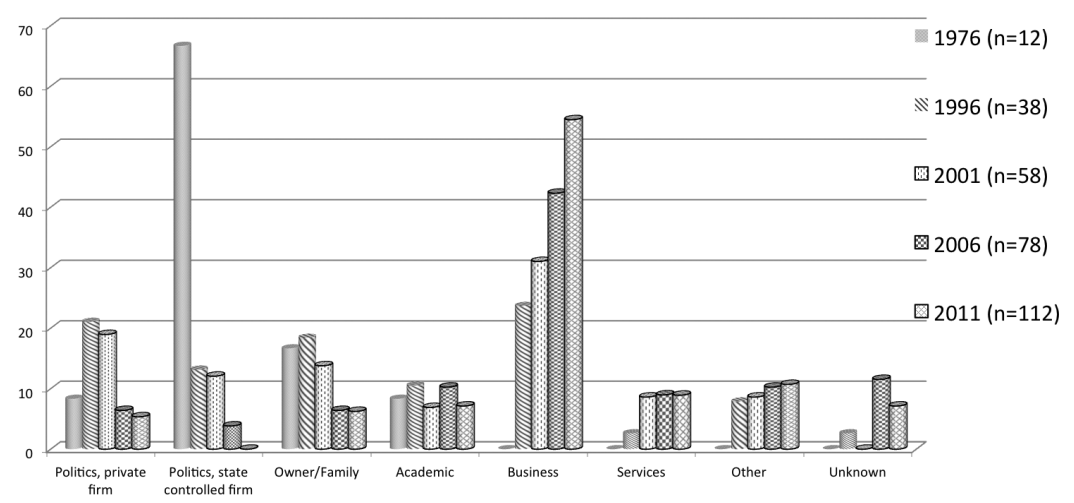

Figure 6 Background of female board members of the largest 250 firms in 1976-2011.

Yet, democratization from within remains relatively modest, and the incumbent corporate elite applies several strategies to keep female board members from becoming an all too important factor in the Dutch business community. Firstly, they invited females from adjacent elites into their boards: initially from politics and academia, later from other countries. Members from other elites pose less of a threat because they are not fully a part of the corporate elite. And foreign females are arguably less threatening because foreign directors hardly participate in national elite business networks. ${ }^{57}$

Secondly, although women increasingly occupy the boardroom, they still do not reach the more powerful positions. The first time a female rose to the position of chair of supervisory board of a major Dutch firm was in 2009, when Marike van Lier Lels took this position after the former chairman of USG suddenly passed away. And in a similar vein, the entrance of females into the ranks of interlocking directors-the inner circle of the corporate elite-remains limited. The number of female directors with more than one board position at the top 250 firms remains stable from 1996 (eight interlockers) through 2001 (six interlockers) to 2006 (eight interlockers). In 2011, their numbers more than doubled to a total of eighteen interlockers.

Thirdly, it has been argued that the beneficial contribution of female board members comes with a threshold effect. ${ }^{58}$ Just one female entering the board may be ignored, and thus the internal capacities will not increase and may even decline if the presence of the female creates tension. With two female board members, there is somewhat more of a critical mass, but typically observers state that with three 
females on the board, there is an actual change in board dynamics. ${ }^{59}$ While females have been entering corporate boardrooms since the 1990s, they are still a minority. More than two females on one board is still very exceptional: in 2011, five Dutch supervisory boards have three female members, and three of these organizations are (formerly) state owned (TNT, Alliander, and BNG). At the executive board level, three corporations have two female board members. This all implies that any potential benefits from diversity are still counteracted by negative effects of group dynamics. In sum, the female group of corporate board members still have to find their way into the core of the corporate elite.

\section{Conclusion}

After a century of an all-male corporate elite, females slowly gained access to corporate boards. We have traced how and where females gained access to the corporate boards. The perspective we applied was that of an incumbent elite that has to open up its ranks and by doing so allows for more descriptive representation. Rather than asking the question why there are so few women on corporate boards, we asked how an incumbent corporate elite allows for democratization of its ranks. We have used the term democratization in the Tocquevillian sense of the word: (more) equality of access to positions of power and influence for all citizens. Building on the scholarly literature, we distinguished between democratization driven from within and from outside the corporate elite. Accordingly, we have formulated a number of expectations (see table 1).

When, during the 1970s, the first females started to enter corporate boards, this was mainly through outside pressure. State-controlled firms were the first to allow females on their board. These initial female board members were politicians, partly occupying their positions ex officio. In a way, the state paved the way for females to join the corporate elite. One might say that political democracy induced the democratization of the business elite. The entry of female politicians in the boardrooms of state-controlled firms also had a more lasting effect on the wider business community. After their initial entry in the boards of state-controlled firms, female politicians were also recruited as board members of other large corporations. Yet, even in the twenty-first century, former state-owned firms still had more Dutch females on their executive boards.

59. Erkut, Kramer, and Konrad, “Critical Mass”; Kramer et al., Critical Mass on Corporate Boards. 
Democratization from within the corporate elite did follow externally driven democratization (as we expected). Initially, the incumbent corporate elite preferred female politicians over females with a business background. This may also be a supply side issue: there was only a very small group of females with business experience. It is only after the turn of the century that we find an increasing number of female board members with a business background. These female board members with a business background are more often than not from foreign origin.

The Dutch corporate elite has increased its descriptive representation over the past decades. The total absence of females at the highest levels of corporate decision making is now gone. We see this as part of the democratization of Dutch society. Increasingly so, powerful positions can be obtained because of merits, rather than through ascription. Tocquevillian democratization can also be conceived a move toward meritocracy. Social homogeneity among the corporate elite is decreasing. At the same time, it is clear that we should not overstate the heterogeneity of the corporate elite. In order to ascend to and be invited to a board, one needs to adhere to certain norms, practices, and behavior. This goes for both males and females. The enhancement of female board participation builds on both equal rights and functionalist arguments. And often, these two work in tandem. Both lines of argumentation provide for a sense of legitimacy to female board participation. The case of the Netherlands suggests that if more equal participation in corporate boards is an important political goal, the incumbent corporate elite might well need a helping hand in making corporate governance more democratic.

This study is limited for at least two reasons. First of all, we deliberately focused on the "demand side" for female board participation. It goes without saying that we cannot fully understand the processes and mechanisms that lead to a more equal distribution of powerful positions between men and women if we do not consider supply side issues as well. Increased levels of education, changing distributions of household tasks within families, and changing preferences of working hours all play a role in the ascendance of females to the corporate board. Here, we show that the demand side plays a crucial role. A second limitation is that we look at board composition and do not delve deeper into the black box of board decision making. Further investigation of the nature of women's board participation is needed: to what extent do they influence the board dynamics. Are they able to make contributions to the decision-making process? In other words, how much influence do women have vis-à-vis their male counterparts? 
The implications of our study extend well beyond the Dutch case. Our study shows that research into board diversity can learn quite a lot from considering the paths through which women moved and continue to move onto corporate boards. It is important to recognize that businesswomen are not a homogenous group. We have been able to show how particular paths have been important in particular periods and how over time several pathways to the boardroom mutually have reinforced each other. This take on the important issue of female representation at the corporate apex can help us to better understand why there are still few women on corporate boards but also, how those that are made it there. We hope that our study of pathways to the Dutch corporate elite will inspire new directions in corporate elite studies.

\section{Funding}

Eelke M. Heemskerk received funding from Netherlands Organisation for Scientific Research.

\section{Bibliography of Works Cited}

\section{Books}

Condorcet, Jean-Antoine-Nicolas de Caritat (Marquis de). La Politique De Condorcet. Paris: Payot \& Rivages, 1996.

De Gouges, Olympe. "Declaration of the Rights of Woman and Citizen." http:// chnm.gmu.edu/revolution/d/293/, 1791.

Domhoff, G. William. The Bohemian Grove and Other Retreats. A Study in Ruling-class Cohesiveness. New York: Harper \& Row, 1975.

- The Higher Circles. The Governing class in America. New York: Random House, 1970.

Fennema, Meindert, and Eelke M. Heemskerk. Nieuwe Netwerken: De Ondergang Van De NV Nederland. Amsterdam, the Netherlands: Bert Bakker, 2008.

Heemskerk, Eelke M. Decline of the Corporate Community. Network Dynamics of the Dutch Business Elite. Amsterdam, the Netherlands: Amsterdam University Press, 2007.

Helmers, H. M., Robert J. Mokken, R. C. Plijter, and Frans N. Stokman. Graven Naar Macht. Amsterdam, the Netherlands: Van Gennep, 1975.

Janis, Irving. Groupthink: Psychological Studies of Policy Decisions and Fiascoes. Boston, MA: Houghton Mifflin Company, 1982.

Pitkin, Hannah F. The Concept of Representation. Berkeley, CA: University of California Press, 1967.

Podolny, J. M. Status Signals: A Sociological Study of Market Competition. Princeton: Princeton University Press, 2005. 
Richardson, I. N., A. Kakabadse, and N. Kakabadse. Bilderberg People: Elite Power and Consensus in World Affairs. London and New York: Oxon: Routledge, 2011.

Scott, John. Corporate Business and Capitalist Classes. New York: Oxford University Press, 1997.

Stokman, Frans N., Rolf Ziegler, and John Scott. Networks of Corporate Power. Cambridge, UK: Polity Press, 1985.

\section{Articles and Essays}

Adams, R. B., and D. Ferreira. "Women in the Boardroom and Their Impact on Governance and Performance." Journal of Financial Economics 94, no. 2 (2009): 291-309.

Burt, Ronald S. "Structural Holes and Good Ideas." American Journal of Sociology 110, no. 2 (2004): 349-99.

Campbell, K., and A. Minguez-Vera. "Gender Diversity in the Boardroom and Firm Financial Performance." Journal of Business Ethics 83, no. 3 (2008): 435-51.

Carroll, William K., and Meindert Fennema. "Is There a Transnational Business Community?” International Sociology 17, no. 3 (2002): 393-419.

Carter, D. A., F. D’Souza, B. J. Simkins, and W. G. Simpson. “The Gender and Ethnic Diversity of US Boards and Board Committees and Firm Financial Performance." Corporate Governance: An International Review 18, no. 5 (2010): 396-414.

Centola, Damon, and Michael W. Macy. "Complex Contagions and the Weakness of Long Ties.” American Journal of Sociology 113, no. 3 (2007): 702-34.

Croson, R., and N. Buchan. "Gender and Culture: International Experimental Evidence from Trust Games." The American Economic Review 89, no. 2 (1999): 386-91.

Dalton, D. R., Catherine M. Daily, Alan E. Ellstrand, and Jonathan L. Johnson. "Meta-analytic Reviews of Board Composition, Leadership Structure, and Financial Performance.” Strategic Management Journal 19, no. 3 (1998): 269-90.

Del Giudice, M., T. Booth, and P. Irwing. "The Distance between Mars and Venus: Measuring Global Sex Differences in Personality." PloS One 7, no. 1 (2012): e29265.

Erhardt, N. L., J. D. Werbel, and C. B. Shrader. "Board of Director Diversity and Firm Financial Performance." Corporate Governance: An International Review 11, no. 2 (2003): 102-11.

Erkut, S., V. W. Kramer, and A. M. Konrad. "Critical Mass: Does the Number of Women on a Corporate Board Make a Difference?" In Women on Corporate Boards of Directors: International Research and Practice, edited by Susan Vinnicombe, Val Singh, Ronald J. Burke, Diana Bilimoria, and Morten Huse, 222-230. Cheltenham: Edward Elgar Publishing, 2008.

Fairfax, L. M. "Clogs in the Pipeline: The Mixed Data on Women Directors and Continued Barriers to their Advancement." Maryland Law Review 65 (2006): 579. 
Fairfax, Lisa. "Board Diversity Revisited: New Rationale, Same Old Story?" North Carolina Law Review 89 (2011): 854.

Fennema, Meindert, and Huibert Schijf. "Elites in Nederland.” In Nederlandse Elites in De Twintigste Eeuw: Continuiteit en Verandering, edited by Meindert Fennema and Huibert Schijf, 7-14. Amsterdam, the Netherlands: Amsterdam University Press, 2004.

Fleron, Frederic J., Jr. "Cooptation as a Mechanism of Adaption to Change: The Soviet Political Leadership System.” Polity 2, no. 2 (Winter 1969): 176-201.

Forbes, D. P., and F. J. Milliken. "Cognition and Corporate Governance: Understanding Boards of Directors as Strategic Decision-Making Groups.” Academy of Management Review 24, no. 3 (1999): 489-505.

Granovetter, Mark S. "The Strength of Weak Ties." American Journal of Sociology 78 (1973): 1360-80.

Greve, H. R., and H. Mitsuhashi. "Power and Glory: Concentrated Power in Top Management Teams." Organization Studies 28, no. 8 (2007): 1197-221.

Haasnoot, Shirley. "Ondernemer Paul Fentener Van Vlissingen: 'Ik moest iets studeren waarmee ik altijd mijn boterham kon verdienen'." Historisch Nieuwsblad 11, no. 5 (2002): 4-9.

Heemskerk, Eelke M. "De Internationalisering van de Nederlandse Financieel Economische Bestuurselite." In Nederlandse Elites in De Twintigste Eeuw, edited by Meindert Fennema, 39-56. Amsterdam, the Netherlands: Amsterdam University Press, 2004.

Heemskerk, Eelke M., and Meindert Fennema. "Network Dynamics of the Dutch Business Elite.” International Sociology 24, no. 6 (2009): 807-32.

Heemskerk, Eelke M., Robert J. Mokken, and Meindert Fennema. "The Fading of the State: Corporate-Government Networks in the Netherlands." International Journal of Comparative Sociology 53, no. 4 (2012): 253-74.

Heminway, J. M. "Sex, Trust, and Corporate Boards." Bepress Legal Series (2006). Working Paper 1527, August 2002.

Jianakoplos, Nancy Ammon, and Alexandra Bernasek. "Are Women More Risk Averse?” Economic Enquiry 36, no. 4 (October 1998): 620-30.

Kramer, V. W., A. M. Konrad, S. Erkut, and M. J. Hooper. "Critical Mass on Corporate Boards: Why Three or More Women Enhance Governance." Directors Monthly 31, no. 2 (February 2007): 19-22.

Langevoort, D. C. "Puzzles about Corporate Boards and Board Diversity." North Carolina Law Review 89 (2011): 841-1055.

Lückerath-Rovers, M. "Women on Boards and Firm Performance." Journal of Management and Governance 17, no. 2 (May 2013): 491-509.

McPherson, Miller, Lynn Smith-Lovin, and James M. Cook. "Birds of a Feather: Homophily in Social Networks." Annual Review of Sociology 27 (2001): 415-44.

Miller, T., and M. del Carmen Triana. "Demographic Diversity in the Boardroom: Mediators of the Board Diversity-firm Performance Relationship." Journal of Management Studies 46, no. 5 (2009): 755-86. 
Pettigrew, Andrew M. “On Studying Managerial Elites.” Strategic Management Journal 13 (Winter 1992): 163-82.

Schmidt, S. L., and M. Brauer. "Strategic Governance: How to Assess Board Effectiveness in Guiding Strategy Execution.” Corporate Governance: An International Review 14, no. 1 (2006): 13-22.

Tocqueville, Alexis de. "Democracy in America." In Great Books of the Western World, edited by Mortimer J. Adler, vol. 44. Chicago: Encyclopaedia Britannica (1840), 1990.

Van Veen, Kees, and Ilse Marsman. "How International Are Executive Boards of European MNCs? Nationality Diversity in 15 European Countries." European Management Journal 26, no. 3 (2008): 188-98.

Visser, J. "The First Part-Time Economy in the World: A Model to be Followed?" Journal of European Social Policy 12, no. 1 (2002): 23-42.

Washington, M., and Edward J. Zajac. "Status Evolution and Competition: Theory and Evidence." The Academy of Management Journal 48, no. 2 (2005): 282-96.

Westphal, James D., and Poonam Khanna. "Keeping Directors in Line: Social Distancing as a Control Mechanism in the Corporate Elite." Administrative Science Quarterly 48 (2003): 361-98.

Wilkins, David B. 'From 'Separate Is Inherently Unequal' to 'Diversity is Good for Business': The Rise of Market-Based Diversity Arguments and the Fate of the Black Corporate Bar." Harvard Law Review 117, no. 5 (March 2004): 1548-615.

\section{Newspapers and Magazines}

Mees, Heleen, and Neelie Kroes. "Meer Vrouwen Aan De Top - Desnoods Verplicht.” NRC Handelsblad, October 17, 2006.

Pfister, Rene, and Christoph Schult. "Gender Quota Debate: We Have to Rethink Our Entire Social Model.” Spiegel Online, March 27, 2012.

Rhode, D., and A. Packel. "Diversity on Corporate Boards: How Much Difference Does Difference Make?" Rock Center for Corporate Governance at Stanford University Working Paper No. 89 (2010).

\section{Reports}

Alliance for Board Diversity. "Women and Minorities on Fortune 100 Boards." http://theabd.org/Women \% 20and \% 20Minorities \% 20on \% 20F100\% 20 Boards_2008.pdf,2008.

Catalyst. Women on Board: Quick Takes. New York: Catalyst, 2012.

Portegijs, W., B. Hermans en V. Lalta. Emancipatiemonitor 2006. Den Haag: Sociaal en Cultureel Planbureau/Centraal Bureau voor de Statistiek, 2007.

Merens, Ans, Marion van den Brakel, Marijke Hartgers, and B. Hermans. Emancipatiemonitor 2010. Den Haag: Sociaal en Cultureel Planbureau and Centraal Bureau voor de Statistiek, 2011. 
Merens, Ans, MarijkeHartgers, and Marion van den Brakel.Emancipatiemonitor 2012. Den Haag: Sociaal en Cultureel Planbureau and Centraal Bureau voor de Statistiek, 2013.

\section{Unpublished Works}

Barnes, Roy C. "The Organizational Mosaic of U.S. Corporate Directors." Paper Presented at the Annual Meeting of the International Network for Social Network Analysis, Corfu Island, Greece, May 4, 2007. 